\title{
The Study of Rice Husk as Co-Digestion Together with Cow Dung is Biogas Production of Anaerobic Digester
}

\author{
Sania Septiani Mulyawan ${ }^{1,2}$, Dini Widyani Aghnia ${ }^{1,2}$, Elisabeth Rianawati ${ }^{1, *}$, Enri Damanhuri ${ }^{2}$, Marisa \\ Handjani $^{2}$, Tri Padmi ${ }^{2}$, Bridgid Chin Lai Fui ${ }^{3}$, Menandro Acda ${ }^{4}$, Pornkamol Unrean ${ }^{5}$ \\ ${ }^{1}$ Resilience Development Initiative, Bandung - Indonesia \\ ${ }^{2}$ Department of Environmental Engineering, Faculty of Engineering, Institute Teknologi Bandung - Indonesia \\ ${ }^{3}$ Curtin University Sarawak, CDT 250, 98009 Miri, Sarawak, Malaysia \\ ${ }^{4}$ University of the Philippines Los Banos, Pedro R. Sandoval Ave, Los Baños, Laguna, Philippines \\ ${ }^{5}$ National Center for Genetic Engineering and Biotechnology, 113 Thailand Science Park Paholyothin Road, Klong 1, Klong \\ Luang, Pathumthani 12120, Thailand
}

\begin{abstract}
One of alternative waste-to-energy technologies to treat organic waste is anaerobic digestion. This study conducted by three stage of experiments using the laboratory scale biogas production from cow dung and rice husk as co-digestion. Based on the first stage experiments, TS $10 \%$ gave the highest accumulation of biogas $458 \mathrm{ml}$ and 506,95 ml. In the second stage of the experiments, $10 \mathrm{ml}$ media in TS $20 \%$ gave the highest accumulation of biogas production $(743.1 \mathrm{ml})$. The last stage of experiments showed that Blank TS $30 \%$ with $5 \mathrm{ml}$ media gave the highest accumulation of biogas production $(922.2 \mathrm{ml})$. From the last stage we can conclude that the presented of rice husk as a co-digestion didn't give the significant effect to increase biogas production in anaerobic digestion, at least at room temperature. This caused by the high lignin and cellulose concentration in the rice husk that might resist or inhibit the production of biogas production. This is contrast situation when TS $40 \%$ occured, the existing of rice husk in AD will give positive impact to biogas produce.
\end{abstract}

Keywords: anaerobic digestion; cow dung; rice husk ; co-digestion.

\section{Introduction}

Anaerobic digestion performance is heavily influence by the characteristic of organic material such as food waste, manure, sewage sludge, organic fraction of municipal solid waste, and energy corps, and others [1]. The popularity of the technology is due to its ability to turn organic waste into energy [2].

In Indonesia, cow dung volumes are increasing annually and most of them are disposed without any treatment. Anaerobic digestion could be an alternative option to treat the cow dung and thus reducing the cost of disposal and produce biogas for energy recovery. Methane and carbon dioxide which is mainly contained in biogas production, can be used as renewable energy sources [3].

Other type of organic waste that is abundant in rural area is agricultural waste, such as properly such as rice husk, rice residues and rice straw from the drying process. The waste is abundant particularly during harvest and is mostly burnt in the field causing air pollutant. As a matter of fact, these wastes have high carbon content which can be used as for biogas production through anaerobic digestion process. However as the rice residues are to optimize anaerobic digestion performance and obtaining energy by considering digestion of rice residues are difficult to degrade, the parameters of the anaerobic digestion should be set properly [4].

Table 1 Characteristic of Rice Husk Reported in Literatures

\begin{tabular}{|c|c|c|c|}
\hline Parameters & $\begin{array}{l}\text { Pillaier, } \\
1988\end{array}$ & $\begin{array}{l}\text { Bronzeoak, } \\
2003\end{array}$ & $\begin{array}{c}\text { Kumar, } \\
\text { P.Senthil, } \\
2010\end{array}$ \\
\hline Crude protein, $\%$ & $1.7-2.6$ & - & - \\
\hline Crude fiber, $\%$ & $\begin{array}{c}31.71- \\
49.92\end{array}$ & - & - \\
\hline Mineral Ash, \% & - & - & 13.87 \\
\hline Pentasans, $\%$ & $\begin{array}{l}16.94- \\
21.95\end{array}$ & - & - \\
\hline Crude fat, \% & 0.38 & - & - \\
\hline $\begin{array}{c}\text { Nitrogen free } \\
\text { extract, } \%\end{array}$ & $\begin{array}{l}24.7- \\
38.79\end{array}$ & - & - \\
\hline Cellulose, \% & $\begin{array}{c}34.34- \\
43.80\end{array}$ & - & 31.12 \\
\hline Ash, $\%$ & $\begin{array}{l}13.16- \\
29.04\end{array}$ & $22.0-29.0$ & - \\
\hline Hemicellulose, \% & - & - & 22.48 \\
\hline Lignin, $\%$ & $\begin{array}{c}21.40- \\
46.97\end{array}$ & - & 22.34 \\
\hline $\begin{array}{c}\text { Bulk Density } \\
(\mathrm{kg} / \mathrm{m} 3)\end{array}$ & - & $96-160$ & - \\
\hline Nitrogen, $\%$ & - & $0.23-0.32$ & - \\
\hline Carbon, $\%$ & - & $\approx 35.0$ & - \\
\hline Moisture, $\%$ & - & $8.0-9.0$ & - \\
\hline Hydrogen, \% & - & $4.0-5.0$ & - \\
\hline
\end{tabular}

* Corresponding author: erianawati@gmail.com 


\begin{tabular}{|c|c|c|c|}
\hline Parameters & $\begin{array}{c}\text { Pillaier, } \\
1988\end{array}$ & $\begin{array}{c}\text { Bronzeoak, } \\
2003\end{array}$ & $\begin{array}{c}\text { Kumar, } \\
\text { P.Senthil, } \\
2010\end{array}$ \\
\hline Oxygen, \% & - & $31.0-37.0$ & - \\
\hline Sulphur, \% & - & $0.04-0.08$ & - \\
\hline
\end{tabular}

Co-digestion of several feedstocks, for example, grain waste-rice husk, banana- plantation peels, sewagebrewery sludge, pig waste-cassava peels, will increase methane production up to $60 \%$ in comparison to the methane production from single substrates [7] [9] [28] [29]. The flexibility of anaerobic digestion also enable a wide range of organic substrate such as industrial wastes such as carbonated soft drink sludge, animal and plant wastes, and brewery wastes that can be used as digester feed [8] [19] [20] [21] [22] [23]. In this study we will used rice husk (RH) as co-digestion to anerobic digestion. However based on the Table 1, lignin in RH have outstanding micro-biological characteristics that resistance to enzymatic degradation [17].

This paper will contain three experiment that related each others. The aim of this paper was explore and investigate rice husk together with cow dung can be a source of renewable energy through anaerobic digestion technology with variation of total solid, composition rice husk and cow dung, and nutrient

\section{Materials and Method}

\subsection{First Experiment}

Goal of first experiment was to know the best total solid that can produce the highest biogas by cow dung only, without the presented of rice husk. The first step was prepared basic nutrient and acidified brine solution.

Table 2 Composition of nutrient

\begin{tabular}{|c|c|c|}
\hline Substances & Mass & Unit \\
\hline $\mathrm{CaCl}_{2}$ & 5 & gram \\
\hline $\mathrm{K}_{2} \mathrm{HPO}_{4} \cdot \mathrm{H}_{2} \mathrm{O}$ & 200 & gram \\
\hline $\mathrm{NH} 4 \mathrm{CL}$ & 100 & gram \\
\hline
\end{tabular}

Put all the substances into one liter of glass bottle and filled by aquades until the bottle was full. The substance which is $\mathrm{K}_{2} \mathrm{HPO}_{4} \cdot \mathrm{H}_{2} \mathrm{O}$ and $\mathrm{CaCO}_{3}$ was needed to achieve $\mathrm{pH}$ during digestion, they provided a stable environment inside digester [16].

After that brine solution was acidified by saturating $\mathrm{NaCl}$ in distilled water. The addition of brine solution is to inhibit biogas dissolution in the water when biogas measurement occurred and then input cow dung, aquades, and nutrients into the anaerobic digester as seen on the Table 2

- Table 3 Composition of cow dung, aquades, and nutrient of experiment 1

\begin{tabular}{|l|l|l|l|l|}
\hline Substances & TS 20\% & TS 15\% & TS 10\% & Unit \\
\hline
\end{tabular}

\begin{tabular}{|c|c|c|c|c|}
\hline Cow Dung & 140,5 & 137,4 & 134,6 & $\mathrm{ml}$ \\
\hline Aquades & 110 & 115 & 120 & $\mathrm{ml}$ \\
\hline Nutrient & 30 & 30 & 30 & $\mathrm{ml}$ \\
\hline
\end{tabular}

Next step, was measured the biogas produced by using water replacement method with the steps as follows. First, connected the balloon with plastic hose, give a small amount of water (as an indicator of the presented gas that will come out from the balloon), clipped the plastic hose by paper clip and put the needles at the end of the plastic hose. Injected the needles into the bottle (as a laboratory scale reactor) and opened the paper clip. Wait until the bubbles from the water indicator has stopped forming and clipped again by paper clip. After that, connected the balloon to buchner flask which contain acidified brine solution and pressed until all the gas come out from the balloon. The water that replaced into the other container was measured to know the gas that produced in the anaerobic digester.

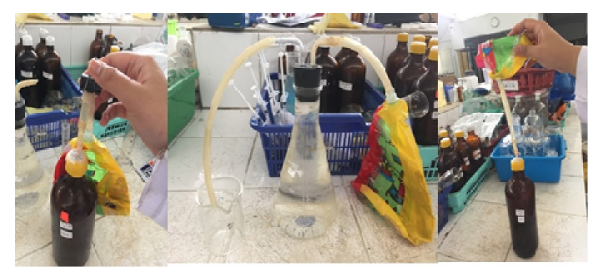

Fig. 1 Biogas Measurement Method

\subsection{Second Experiment}

Second experiment was done to determine the amount of nutrient should be input into anaerobic digester to support the process. The anaerobic digester we made is by input $150 \mathrm{gr}$ cow dung (CD) and $13 \mathrm{gr}$ rice husk $(\mathrm{RH}), 160 \mathrm{ml}$ aquades and the nutrient we had made before (with variation $0 \mathrm{ml}, 5 \mathrm{ml}, 10 \mathrm{ml}$ ). After that measured the biogas with the method that we used in first experiment.

Table 4 Composition of RH, CD and Aquades for Second Experiment

\begin{tabular}{|c|c|c|c|}
\hline Substances & Mass & Unit & Density \\
\hline $\begin{array}{c}\text { Rice Husk } \\
25 \%\end{array}$ & 13 & gram & $0,258 \mathrm{~g} / \mathrm{ml}$ \\
\hline $\begin{array}{c}\text { Cow Dung } \\
75 \%\end{array}$ & 150 & gram & $1 \mathrm{~g} / \mathrm{ml}$ \\
\hline Aquades & 160 & $\mathrm{ml}$ & $1 \mathrm{~g} / \mathrm{ml}$ \\
\hline
\end{tabular}

\subsection{Third Experiment}

The purpose of the last experiment was to know the best total solid of $\mathrm{CD}$ and $\mathrm{RH}$ composition in $\mathrm{AD}$ experiment to yield the highest biogas. Almost steps in third experiment were same as first experiment. The difference is only on the materials were input into the reactor. The materials can be seen on the table down below. Those experiments was doing with duplo method, 
in each TS variance was made twice. The composition of $\mathrm{AD}$ in third experiment can be seen on Table 4 .

\begin{tabular}{|c|c|c|c|c|c|c|c|}
\hline \multirow{2}{*}{ 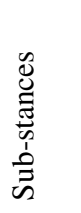 } & \multicolumn{2}{|c|}{ TS $20 \%$} & \multicolumn{2}{|c|}{ TS $30 \%$} & \multicolumn{2}{|c|}{ TS $40 \%$} & \multirow[b]{2}{*}{$\underset{\emptyset}{\vec{\Xi}}$} \\
\hline & $\begin{array}{l}\mathrm{RH} \\
+ \\
\mathrm{CD}\end{array}$ & $\begin{array}{l}\frac{y}{\vec{I}} \\
\frac{\vec{a}}{\oplus}\end{array}$ & $\begin{array}{l}\mathrm{RH} \\
+ \\
\mathrm{CD}\end{array}$ & $\begin{array}{l}\frac{.}{J} \\
\frac{\vec{\omega}}{m}\end{array}$ & $\begin{array}{l}\mathrm{RH}+ \\
\mathrm{CD}\end{array}$ & $\frac{\underline{J}}{\frac{\pi}{n}}$ & \\
\hline $\begin{array}{l}\text { Cow } \\
\text { Dung }\end{array}$ & 150 & 150 & 150 & 150 & 150 & 150 & $\mathrm{gr}$ \\
\hline $\begin{array}{l}\text { Rice } \\
\text { Husk }\end{array}$ & 13 & 0 & 13 & 0 & 13 & 0 & $\mathrm{gr}$ \\
\hline $\begin{array}{l}\text { Aqua } \\
\text { des }\end{array}$ & 160 & 160 & 140 & 140 & 120 & 120 & $\mathrm{ml}$ \\
\hline $\begin{array}{l}\text { Nutri } \\
\text { ent }\end{array}$ & 5 & 5 & 5 & 5 & 5 & 5 & $\mathrm{ml}$ \\
\hline
\end{tabular}

Table 5 Composition of Substances in Third Experiment

Table 6 Characteristic of Inoculum, substrate, and mixture of feedstock

\begin{tabular}{|l|l|l|}
\hline \multicolumn{1}{|c|}{ Parameters } & \multicolumn{1}{|c|}{ Inoculum } & \multicolumn{1}{c|}{ Rice Husk } \\
\hline Total Solid (\%) & 92,1 & 8,9 \\
\hline Volatile Solid (\%) & 74,3 & 83 \\
\hline
\end{tabular}

\section{Result and Discussion}

\subsection{Biogas Production Experiment 1}

Total Solid is an important thing in anaerobic digester performance to determine condition for optimum gas production [11]. The content of TS will affect performance of digestion in $\mathrm{AD}$ digester and methane production efficiency [12]

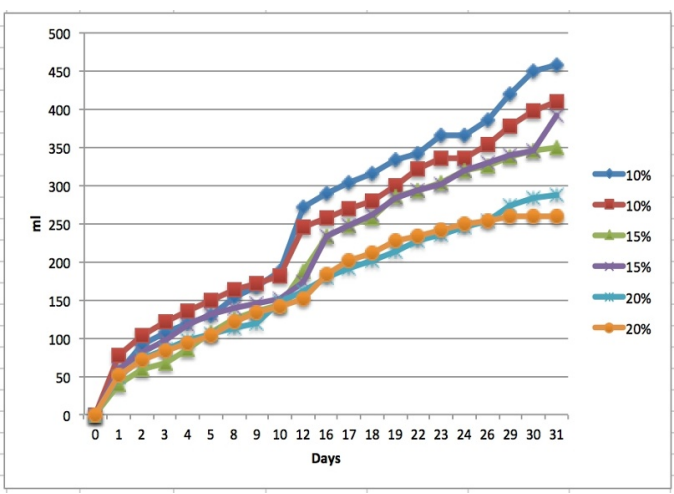

Fig. 2 Biogas Result of First Experiment

The result of the second experiment in the figure above showing that TS $10 \%$ is the suitable total solid would yield biogas production among another TS content ( TS $15 \%$, TS20\%) for cow dung composition in anaerobic digester. Abbasi Gundeouz et al, study depicted that for TS content increasing from 10\%-20\% the total methane production in batch anaerobic digester with mesophilic conditions would correspondingly decrease [13]. The previously work also by ForsterCarneiro at al., showed if there is an increasing TS from $20 \%-30 \%$ there will be decreasing the biogas methane yield, it means that low TS will make a positive effect for AD performance [11]. This corresponds with another previous work in the batch anaerobic digestion of food waste which depicted that lower total solid content yielded higher biogas production. In addition, using TS lower than $20 \%$ will have positive impact to the methane product. [14].

\subsection{Biogas Production Experiment 1}

The second experiment we did by variate the amount of media and keep the other treatments same for all samples. Based on Fig. 2, rice husk and cow dunk (25: 75) with media variation $0 \mathrm{ml}, 5 \mathrm{ml}$, and $10 \mathrm{ml}$ give a different results. Anaerobic digestion with $10 \mathrm{ml}$ media produced the highest gas volume, continued by $5 \mathrm{ml}$ media and the lowest is $0 \mathrm{ml}$ media.

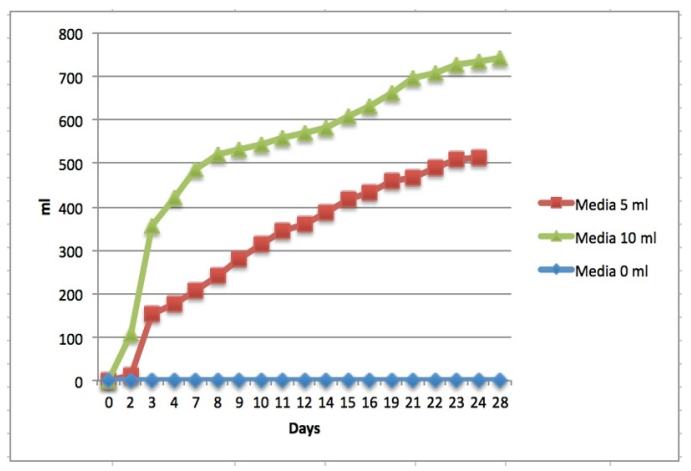

Fig. 3 Biogas Result of Second Experiment

In $10 \mathrm{ml}$ media, the most significant gas produced from day 2 to day 3. After day 3 the gas still increasing but was not significant. This is in accordance with $5 \mathrm{ml}$ media, gas produced slowly started from day 2, increased significantly from day 3 to day 4 , and still continued to produce gas until the end of the day of experiment.

In the opposite, $0 \mathrm{ml}$ media gas did not produced until the end of experiment. This happened because of $\mathrm{RH}$ consists of high lignin and cellulose content which made the enzymatic degradation become inhibited and affected the overall biogas production [6]. Media give impact to the rice husk and cow dunk because media help the microorganism to degrade the cellulose and lignin from rice husk so they could produce more gas. This similar with Iyagba (2009), research that rice husk as co-digestion with cow dung can not be together to produce methane gas, at least at the room temperature without any media.

\subsection{Biogas Production Experiment 3}

Another experiment conducted is experiment 3 which used rice husk - cow dung composition as feedstock AD. This result experiment shown, TS $40 \%$ was the best 
condition to produce biogas for RH-CD composition among TS $20 \%$,TS $30 \%$. The result also shown Blanko TS $30 \%$ was the best TS condition for CD composition. Difference TS condition from experiment 2 and 3 occurred because of the difference substrate had been used. This result also showing that biogas still produce increasingly from TS $10 \%$, TS $20 \%$ and TS $30 \%$ for CD composition. As shown in this figure, biogas produced in 3rd day was restrained for all variation. This might be caused by the production of Volatile Fatty Acids (VFA) that obtained from acid forming bacteria which subsequently decreased $\mathrm{pH}$ and reduced the growth of methanogenic bacteria. As such, methanogenesis become lower in initial biogas production stage [15] [30].

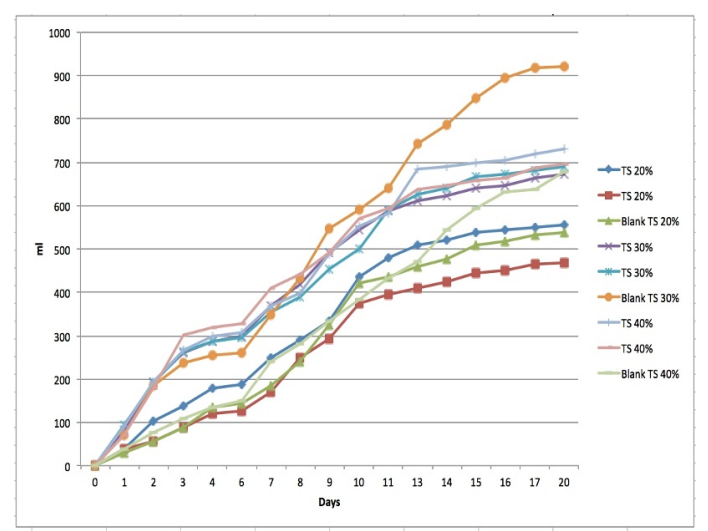

Fig. 4 Biogas Result of Third Experiment

Knowing the presented effect of rice husk, we comparing biogas produce between TS variation and blank variation. In TS $20 \%$, blank produce the biogas with the amount almost the same as TS $20 \%$ RH-CD composition. There is a significance difference in TS $30 \%$, the blank produced biogas more than TS 30\% RHCD composition. The result of TS $20 \%$ and $30 \%$ was contrast with result of TS $40 \%$, in TS $40 \%$ the blank producing less biogas than TS 40\% RH-CD composition. Therefore in general result, showed that TS $30 \%$ is the optimal condition of gas production without and $\mathrm{RH}$ and TS $40 \%$ produced highest gas with addition of RH. Generally, the existence of rice husk will decrease the produced of gas if we conducted in TS $30 \%$ and $20 \%$, but in TS $40 \%$ rice husk will increased the biogas produce.

The high level of cellulose and lignin in the rice husk made enzymatic degradation become resistant and ultimately reduce the biogas production [6]. Nonetheless, with co-digestion with cow dung in experiment 3 and TS $40 \%$ biogas could be produced if we mix RH and CD as AD feedstock.

These results showed that rice husk does not have potential to improve the methane gas production together with cow dung, at least at room temperature. Based on this biogas production study, the contribution of rice husk as the co-digestion together with cow dung does not give significant result, however rice husk that contained in the residue could be used as fertilizer source [14].
Indonesian Central Agency on Statistic (BPS) noted, ther are five provinces that experienced the highest increase of rice production until June 2015. The five provinces are Lampung, West Jaba, South Sumatra, Central Java, and East Java. In Lampung, rice production increased to 541,000 tons in the period (from January to June 2015. Furthermore, the total tice production in West Java in the first half of this year was recorded at 373,000 tons. Then South Sumatra is 434,000 tons. Then the source of rice barn, Central Java produced as much as 954,000 ton. Other granies, East Java, produced as much as 381,000 tons (Badan Pusat Statistik, 2015).Grain harvest in addition to producing rice, also produces rice husks. Based on literature study, the ratio for grain husk is 1:0.24. Means every ton of grain produced will leave the rice husk 0.24 tons (Kesuma, 2014). So the amount of rice husk in the period from January - June 2015 from 5 provinces are 643,920 tons and his number will continue to increase as the rice production also increases, so we have to handle $\mathrm{RH}$ waste before it gets abundant and more dangerous and difficult to treat.

Besides using $\mathrm{AD}$, rice husk is usually burnt by incinerator. However this method can produce emission $\mathrm{CO}$ between $200-2000 \mathrm{mg} / \mathrm{Nm}^{3}$ and $\mathrm{NO}_{\mathrm{x}}$ between 200 $300 \mathrm{mg} / \mathrm{Nm}^{3}$ which is dangerous for human health [27]. The amount of those emission have high possibilities being above of the quality standard based on regulation of the minister of environment and forest of the republic of Indonesia number 70 Year of 2016. Therefore it is expected $\mathrm{AD}$ can be a best solution of rice husk waste management and environmental friendly.

\section{Conclusion}

Rice husk is one of potential renewable energy sources that have abundant amount as waste especially in agricultural countries. Based on this study, to produce biogas through anaerobic digestion method, carbon source could be obtained from rice husk. Furthermore, biogas could be one of alternative energies with environmental-friendly technology to substitute the fossil fuels. The optimum total solid condition for CD only and CD-RH as AD feedstock. This study shows that TS $10 \%$, TS $20 \%$ and TS $30 \%$ for CD composition give the positive impact for biogas produced of AD with TS $30 \%$ produced the highest yield, meanwhile in CD-RH composition TS $40 \%$ produced the highest yield. $\mathrm{RH}$ gave negative impact for AD performance in total solid concentration of $10 \%, 20 \%$ and $30 \%$ except in $40 \%$ condition.

\section{Acknowledgements}

This work is funded by International Foundation for Science 541 (IFS) under Collaborative Research Grant (J-1-D-6037-1). 


\section{References}

1. Mata-Alvarez, J., Dosta, J., Romero-Güiza, M., Fonoll, X., Peces, M., Astals, S., A critical review on anaerobic co-digestion achievements between 2010 and 2013. Renewable Sustainable Energy Rev. 36, 412-427 (2014)

2. Li R., Chen S. and Li X., Anaerobic co-digestion of kitchen waste and cattle manure for methane production. Energy Sources. 31: 1848-1856 (2009)

3. Ibn Abubakar, Baba Shehu Umar \& Nasir Ismail, and, Anaerobic digestion of cow dung for biogas production. ARPN Journal of Engineering and Applied Sciences. 7 (2012).

4. Contreras Velázquez, Luz \& Schelle, H \& Sebrango, Carlos \& Pereda Reyes, Ileana, Methane potential and biodegradability of rice straw, rice husk and rice residues from the drying process. Water science and technology : a journal of the International Association on Water Pollution Research. 65. 1142-9. 10.2166/wst.2012.951(2012).

5. Mohammad Sayyadi, Mangibo A. Ibifuro, Iyagba T. Elijah, Study of Cow Dung as Co-Substrate with Rice Husk in Biogas Production : Scientific Research and Essay Vol.4 (9), pp. 861-866. ISSN 1992-2248 (2009).

6. Pillaier P, "RICE: Post Production Manual", Wiley Eastern yLimited New Delhi, India (1988)

7. Ezekoye VA, Okeke CE, Design, construction and performance evaluation of plastic bio-digester and the storage of biogas. The Pacific J. Sci. Technol. 7: 176-184 (2006)

8. Mackie RI, Bryant MP Anaerobic digestion of cattle waste at mesophilic and thermophilic temperatures. Appl. Mocrobiol.Biotechnol. 43: 346-350(1995).

9. Ilori MO, Adebusoye A, Lawal AK, Awotiwon OA (2007). Production of biogas from banana and plantain peels. Adv. Environ. Biol. 1: 33-38

10. Okeh, C., Onwosi, C. O., \& Fredrick, J. O. C., Biogas Production from Rice Husks Generated From Various Rice Mills in Ebonyi State, Nigeria. Renewable Energy, 62, 204- 208. doi:10.1016/j.renene.2013.07.006 (2014).

11. Yi J, Dong B, Jin J, Dai X, Effect of Increasing Total Solids Contents on Anaerobic Digestion of Food Waste under Mesophilic Conditions: Performance and Microbial Characteristics $\begin{array}{llll}\text { Analysis. PLoS ONE 9(7): e102548. } & \text { ON }\end{array}$ doi:10.1371/journal.pone.0102548 (2014)

12. Pavan P, Battistoni P, Mata-Alvarez J.,Performance of thermophilic semidry anaerobic digestion process changing the feed biodegradability. Water SciTechnol. 41: 75-81 (2014)

13. Abbassi-Guendouz A, Brockmann D, Trably E, Dumas C, Delgene`s JP, et al, Total solids content drives high solid anaerobic digestion via mass transfer limitation. Bioresour Technol. 111: 55-61 (2014)
14. Forster-Carneiro T, Pe'rez M, Romero L, Influence of total solid and inoculum contents on performance of anaerobic reactors treating food waste. Bioresour Technol. 99: 6994-7002 (2008)

15. Vicenta M, Pacheco G, Alamis MLA, Anglo PG, Tan BV, Silverio CM, A study of some factors affecting biogas production from pineapple peelings. In: Bidin $\mathrm{R}$, Chong $\mathrm{CN}$, Wang $\mathrm{CW}$ (Eds.).Proceedings of the second ASEAN Workshop on biogas production applied to the management and utilization of food waste materials. Kaula Terengganu, Malaysia. Pp. 189-202 (1984).

16. Melamane Xolisa, Tandlich Roman, Anaerobic Digestion of Fungally pre-treated distillery wastewater. African Journal of Biotechnology Vol. 6 (17), pp. 1990-1993 (2016)..

17. Alexander M, Introduction to Microbiology, Wiley Eastern Limited, New Delhi, India (1977)

18. Mackie. RI, Bryant MP, Anaerobic digestion of cattle waste at mesophilic and thermophilic temperatures. Appl. Microbiol. Biotechnol. 43: 346350 (1995).

19. Zhang R, Zhang Z, Bio-gasification of rice straw with an anaerobic-phased solids digester system. Bioresour. Technol. 68: 235-245 (1999)

20. Uzodinma EO, Ofoefule AU, Eze JI, Onwuka ND, Biogas production from blends of agro-industrial wastes. Trends in Appl. Sci. Res. 2(6): 554 - 558 (2007).

21. Uzodima EO, Ofoefule AU, Eze JI, Mbaeyi, I, Onwuka ND, Effect of some organic wastes on the biogas yield from carbonated soft drink sludge. Sci. Res. Essay, 3(9): 401-405 (2008).

22. Kivaisi AK, Pretreatment of Robusta coffee hulls and codigestion with cow dung for enhanced anaerobic digestion. Tanz. J. Sci. 28:1-10 (2002)

23. Nagamani B, Ramasamy K, "Biogas Production Technology: An Indian Perspective Fermentation Laboratory, Department of Environmental Sciences, Tamil Nadu Agricultural University, Coimbatore 641 003, India (2007)

24. Bronzeoak, Rice Husk Ash Market Study. DTI, London (2003)

25. Kumar, P.Senthil, Ramakrishnan, K., Kirupha, S.Dinesh, Sivanesa, S, Thermodynamic and Kinetic Studies of Cadmium Adsorption from Aqueous Solution Onto Rice Husk (2010).

26. Kesuma, Wahyu Puja, . Pengembangan Teknologi Alat Produksi Gas Metana dari Pembakaran Sampah Organik dengan Pemurnian Gas menggunakan Zeolite pada Variasi Jumlah Tabung. Universitas Muhammadiyah Surakarta (2010).

27. Armesto, L., Bahillo, A., Veijonen, K. Cabanillas,A., and Otero, J, Combustion Behaviourof Rice Husk in a Bubbling Fluidised Bed.Biomass and Bioenergy . 23: 171 - 179 (2002) 
28. Adeyanju AA, Effect o0f seeding of wood-ash on biogas production using pig waste and cassava peels. J. Eng. Appl. Sci. 3: 242-245 (2008).

29. Babel S, Sae-Tang J, Pecharaply A, Anaerobic codigestion of Iyagba et al. 865 sewage and brewery sludge for biogas production and land application. Int. J. Environ. Sci. Tech. 6: 131-140 (2009)
30. Cuzin, N. et al., Methanogenic fermentation of cassava peel using a pilot plug flow digester, Bioresource Technology. 41: 259-264 (1992). 